\title{
THE ROLE OF THE MILITARY COURTS IN PUNISHING THE CRIMES COMMITTED BY MILITARY PERSONNEL
}

\author{
Alexandru STOIAN \\ "Nicolae Bălcescu" Land Forces Academy, Sibiu, Romania \\ alex_stoian@yahoo.com
}

\begin{abstract}
Having a long tradition in the system of judicial organization in Romania, the military courts represent a category of courts specialized in the prosecution and punishment of the deeds committed by the military. In the context of satisfying the public interest and of the protection of the fundamental rights and freedoms of the citizens, the role of the military courts has always been a strongly individualized one and should, at first sight, enjoy a wider recognition. However, the reforms required by the implementation of the new codes, the Criminal Code and the Criminal Procedure Code, bring into discussion significant restructuring and side with a demilitarization of military courts, required by a better streamlining of the judicial system and by a more adequate implementation of the guarantees of independence and impartiality stipulated by the Constitution of Romania.
\end{abstract}

\section{Keywords: courts, military, judicial, Criminal Code}

\section{Individualization of the military courts in the judicial system}

Along with other courts, the military courts help ensure an effective and quality judicial process, accessible to all subjects of law concerned.

The violation of the legal rules issued by the state disrupts social order and determines the public authorities to intervene in order to restore the balance by engaging legal liability. In this respect, the role of the courts is essential for individualizing and applying the appropriate sanctions. Thus, "justice is the intangible ideal of law, the last and the highest expression of law, which expresses two essential attributes: that of equality and that of generality.’"[1]

One of the controversial issues of the current judicial organization is the need to maintain the military courts as specialized courts. With a rich history and with a well-defined specificity, the military courts have benefited from substantial legal regulations, being one of the most represented categories of specialized courts in the Romanian judicial system.

The purpose of the existence of military courts is closely linked to the protection of three core values, defended and promoted by the military: military duty, military discipline and military order. [2] Through their activity, courts and prosecutors' offices strengthen the action of the legal norms within the military corps and contribute decisively to a better management of the legal responsibility within the military system.

Currently, at the level of interaction with other components of the judiciary, the military courts ensure the fulfillment of the basic measures in the process of transformation of the judicial system generated by the adoption of the new codes, 
the Criminal Code and the Criminal Procedure Code. [3]

Despite these arguments, the current trend is to adapt the act of military justice to the new realities, going so far as to abolish the military courts, considered to be inadequate for an effective judicial system. "The abolition of the military courts is the only solution that contributes to the efficiency of the activity of the justice system and provides all the guarantees of independence and impartiality of the courts and of the judges in Romania," a report of the Superior Council of Magistracy stipulates. [4]

\section{The evolution of the military courts in the autochthonous legal system}

From a historical perspective, the first references to the existence of military courts, distinct from the civilian ones, are made in the 1780 s by the military codes of Byzantine origin that organized two categories of military courts, competent to judge "military cases".

The Organic Regulation of 1812, in Chapter IX, Part IV, set "The Judicial and Discipline Establishment" ("Aşezământul judecătoresc şi disciplinesc"), regulations by means of which the military courts dealt with crimes committed by military of all ranks and by clerks that worked in the army, if these were related to the exercise of their jobs.

"The Military Criminal Code with Its Procedure" (Condica penală ostăşească cu procedura ei") was elaborated in 1852 at the initiative of Prince Barbu Stirbei, in accordance to the foreign law in the field and with the advanced ideas of that period, whereby all military courts were composed of officers and the hearing had a solemn character. It contained 475 articles, grouped into two volumes, the first on crimes and penalties, and the second, on criminal proceedings.

In 1873, under the French influence, the "Code of military justice" was adopted, a code which, together with the change that occurred in 1881, represented a significant regulation in terms of judicial organization, being replaced in 1937 by a new code of military justice, which created the system of discipline councils, military courts, military courts of cassation and justice, in accordance with the stipulations of the Code of Criminal Procedure.

In the period after the Second World War, the organization of the military courts was regulated by Law no. 7/1952 on the organization of military courts and prosecutors' offices, a normative act that was repealed by Law no. 54/1993, for the organization of military courts and prosecutors' offices, a first step in the reorganization of military justice in the context of the socio-political changes.

Law no. 54/1993 is the last normative intended exclusively for the regulation of the military courts because the subsequent legislative changes would not grant a separate regulation to the military courts, although they would maintain for these courts the same special character.

\section{Organization of the military courts in the Romanian judicial system}

Currently, the activity of making justice in military criminal cases is done by the military courts and prosecutors' offices, which are organized on the same principles that govern the judicial authority.

In accordance with the provisions in force of the Romanian legislation, the military and civilian personnel of the Romanian army are held legally responsible under similar conditions as all the citizens of the state, both for acts committed in connection with the service and outside it. In criminal matters, the control of the judicial authority on army structures is exercised through military courts and prosecutors' offices, and in terms of civilian matters, the judicial control is exercised by the civil courts. [5]

As an exception, we would like to mention the constitutional provision that excludes from the control by the 
contentious administrative the acts of military command. [6] According to Law no. 544/2004 of the contentious administrative, the act of military command is "the administrative contentious related strictly to military issues of the work within the military, specific to the military organization, which entail the right of the commanders to give orders to subordinates in matters concerning the leading of the troops, in peacetime or during war, or, where appropriate, in case of conscription."[7]

According to Law no. 304/2004 on the judicial organization, the military courts are organized based on the same rules as the civilian courts, these being: the military courts in Bucharest, Cluj-Napoca, Iasi and Timisoara, the Bucharest Military Court and the Military Court of Appeal.

The same law stipulates that the military courts each have the status of a military unit, with their own indicatives and have trials at their headquarters. "The military courts can also judge Romanian soldiers and members of a multinational force on the territory of other states, given that, according to international conventions, on the territory of the receiving state, the Romanian jurisdiction can be exercised." [8]

The provisions of Law no. 304/2004 on the judicial organization are supplemented by Law no. 303/2004 on the status of magistrates, which establishes the status of the military magistrates who are also active officers. The military judges and prosecutors are paid by the Ministry of National Defence and are required to comply with the military regulations and orders.

The disciplinary responsibility of the military magistrates can be invoked only under Law no. 303/2004, for deviations from official duties, as well as for deeds that affect the prestige of justice, by the Superior Council of Magistracy. [9]

Moreover, due to the specific of the activity, its control can be performed by the
Superior Council of Magistracy, under the same conditions as in the case of the civilian courts.

A contradictory aspect to be mentioned is the attention of the European mechanisms for the protection of human rights, the independence of military judges being called into question, because they have a dual quality: that of judges, subjects to the specific regulations of magistrates, and that of military, officers of the armed forces who have to comply with the military rules and orders.

This represented a subject of litigation at the European Court of Human Rights, the European Court condemning the Romanian State in the following cases: Barbu Anghelescu against Romania, Bursuc against Romania, Maszni against Romania.

The organization of military courts has generated divergences in other states too. For example, in France, the organization in 1962 of a Military Court of Justice following the events in Algeria, prompted multiple negative reactions and led, two decades later, to the closing, with difficulty, of the court, due to the resistance of the existing structures to keep certain privileges arising from the cumulative quality of magistrate and military. [10]

\section{The impact of the reorganization of the current judicial system on the military courts}

Following the adoption of the Criminal Code and Criminal Procedure Code, the situation of the military courts was included on the agenda of the discussion related to the reorganization of the judicial system.

In this context, the abolition of the military courts was proposed as "the right conclusion, which leaves no room for misunderstandings." [11]

In order to make the implementation of the new laws and the rational use of the human resources more efficient, specialists have affirmed that the abolition of military 
courts and the transfer of functions to the civil courts would be a positive element, given the very low volume of cases pending before military courts, and the considerable difference in comparison to the civilian courts. According to the information provided by reports in 2014, a military judge working at a military court had 46 cases per year, compared to 918 cases per year, which a judge at a civilian court had to solve. [12]

Another argument that is brought into discussion is related to the emphasis on the process of demilitarization of certain professional categories that have acquired the status of civil servants and which were no longer tried by military courts and this diminished their power considerably.

The previously mentioned aspect, the dual capacity of the military judges and prosecutors, of magistrates and military, has also been included among the arguments in favor of the abolition of the military courts. "The fact that the military judges have a hybrid status, belonging by their career to the justice system, but by the military career belonging to the Ministry of National Defence; in the absence of an adequate safety net, the guarantee of the independence of military judges is not fully assured."“[13]

\section{Conclusions}

At the same time, it is undeniable that the development of the judiciary and the complex circumstances that led to the appearance and the keeping of the military courts within this system, has strongly individualized the role of the military courts in sanctioning the deeds regulated by legal norms related to national defense and security.

Moreover, the increasing significance of international military cooperation in the geopolitical and geostrategic context of which Romania is part determines a reconsideration of the importance of the military component in achieving all the functions of the state and, implicitly, of the legal system.

As a solution in case of the abolition of the military courts and of the absorption of the functions of military justice by the other components of the justice system, the competence of the military courts can be transferred to civilian courts, without violating the principle of specialization. One argument for this is provided by the fact that currently, in the case of civil, administrative or labor disputes, the hearing of cases in which the subjects are military personnel is made by the civilian courts, and the only category of competence held by the military courts is of criminal nature. This demarche can be supported by the fact that the High Court of Cassation and Justice has no military department, although it judges criminal cases in which military personnel are involved.

A distinct element of the process of reorganization of the courts and of the justice reforms in Romania, the abolition of military courts remains a controversial matter, although the trend that can be observed is in favor of eliminating them and of having their functions taken over by civilian courts.

\section{References}

[1] Ion Avram Dunăreanu, Justiţie, judecător, management, Bucureşti, Editura All Beck, 2005, p. 5.

[2] Petrache Zidaru, Tribunalele militare, un secol şi jumătate de jurisprudenţă, Bucureşti, Editura Universul Juridic, p.331.

[3] Raportul de bilanț pentru anul 2014, Curtea Militară de Apel, București, 2015, http://portal.just.ro/81/Documents/Bilant\%202014.pdf, p. 4, accesat 12.04.2016. 
[4] Raportul Grupului de lucru privind necesitatea efectuării la nivelul Consiliului Superior al Magistraturii a unei analize a impactului implementării şi aplicării noilor coduri, Bucureşti, 2015, http://www.csm1909.ro/csm/index.php?cmd=26, p. 19, accesat 12.04.2016.

[5] Eugen Bădălan, Administraţie militară. Note de curs, Sibiu, Editura Academiei Forţelor Terestre, 2004, p. 83

[6] Mihai Constantinescu, Antonie Iorgovan, Ioan Muraru, Elena Simina Tănăsescu, Constituţia României revizuită, comentarii şi explicaţii, Bucureşti, Editura All Beck, 2004, p. 270.

[7] Legea nr. 544/2004 privind contenciosul administrativ, publicată în Monitorul Oficial al României, Partea I, nr. 1154 din 7 decembrie 2004, art. 2 alin. 1, lit. 1).

[8] Legea $n r$. 304/2004 privind organizarea judiciară, publicată în Monitorul Oficial al României, Partea I, nr. 576 din 29 iunie 2004, art. 57.

[9] Legea nr. 303/2004 privind statutul judecătorilor şi procurorilor, publicată în Monitorul Oficial al României, Partea I, nr. 826 din 13 septembrie 2005.

[10] Ioan Leş, Sisteme judiciare comparate, Bucureşti, Editura All Beck, 2002, p. 66.

[11] Raportul Grupului de lucru privind necesitatea efectuării la nivelul Consiliului Superior al Magistraturii a unei analize a impactului implementării şi aplicării noilor coduri, Bucureşti, 2015, http://www.csm1909.ro/csm/index.php?cmd=26, p. 18, accesat 12.04.2016.

[12] Ibidem, p. 19.

[13] Ibidem, p. 20. 